Article

\title{
The Effects of Camelina "Soheil" as a Novel Biodiesel Fuel on the Performance and Emission Characteristics of Diesel Engine
}

\author{
Seyed Salar Hoseini ${ }^{1}$, Gholamhassam Najafi ${ }^{1, *}$, Barat Ghobadian ${ }^{1}$, Talal Yusaf ${ }^{2}$ \\ and Mohammad Taghi Ebadi ${ }^{3}$ \\ 1 Department of Mechanical \& Biosystems Engineering, Tarbiat Modares University, P.O. Box 14115-336, \\ Tehran, Iran; salar.hoseini@modares.ac.ir (S.S.H.); ghobadib@modares.ac.ir (B.G.) \\ 2 Department of Mechanical and Electrical Engineering, University of Southern Queensland, Toowoomba, \\ QLD 4350, Australia; Talal.Yusaf@usq.edu.au \\ 3 Department of Mechanical \& Biosystems Engineering, Tarbiat Modares University, P.O. Box 14115-336, \\ Tehran, Iran; mt.ebadi@modares.ac.ir \\ * Correspondence: g.najafi@modares.ac.ir; Tel.: +98-21-4829-2322; Fax: +98-21-4829-2200
}

Received: 24 May 2018; Accepted: 16 June 2018; Published: 20 June 2018

\begin{abstract}
In this research, a new cultivar of Camelina "Soheil" seed oil (CSO) was investigated as a novel feedstock for biodiesel production. Maximum oil content of CSO seed was about 29\%. Physical and chemical characteristics of CSO were investigated. The biodiesel production process was optimized by using the response surface methodology (RSM) reaction parameters, including molar ratio (methanol to oil), reaction time, and concentration of catalyst are studied. The result showed that the conversion of biodiesel was $98.91 \%$ under the optimized conditions of 10.18:1 molar ratio and $1.15 \mathrm{wt} \%$ concentration of catalyst for a reaction time of $7.33 \mathrm{~min}$. By investigating the properties of the fuel, it turned out that biodiesel from new cultivar of CSO oil complied with the limits prescribed in the ASTM D6751 standards, and that this seed oil could be introduced as a new feedstock for biodiesel production. Also, the performance and emission of a diesel engine were investigated with CSO biodiesel. All of the engine experiments were performed under the constant speed of $2100 \mathrm{rpm}$ at loads of $0 \%, 25 \%, 50 \%, 75 \%$, and 100\%. Results indicated that by using the biodiesel-diesel blends, the brake power, and the $\mathrm{CO}_{2}$ and NOx emissions increased, while the SFC and $\mathrm{CO}$ and UHC emissions decreased.
\end{abstract}

Keywords: Camelina "Soheil"; biodiesel; ultrasonic; RSM

\section{Introduction}

The increase in population and industrialization significantly increased the demand for energy consumption [1,2]. One of the sectors where energy is significantly consumed is the sector of internal combustion engines (diesel engines). Diesel engines often use fossil resources and mineral-based fuels as their fuel. The use of fossil fuels produces significant amounts of contaminants during combustion due to their chemical composition $[3,4]$. Therefore, no renewable fuels emit pollutants during the combustion. Therefore, the emitted pollutants cause damage to the environment and human health [5]. Vegetable oils are a reliable source for biofuel production [6-10]. The amount of pollutants emitted from biodiesel is significantly lower than fossil fuels [11,12]. Due to the chemical composition of Vegetable oils, the vegetable oils cannot be directly used as fuel in diesel engines. In order to improve the properties of vegetable oils, different methods have been investigated by various researchers. One of the common methods to improve the properties of vegetable oils is transesterification reaction [13-15]. Various studies have been conducted on the production of biodiesel from vegetable oils [16-33]. 
D. Patil et al. [34] evaluated three different types of feedstocks, namely, waste cooking oils, jatropha curcas, and camelina, for biodiesel production under various conditions. The process parameters such as methanol to oil ratio, catalyst concentration, reaction temperature, and reaction time were optimized in the experimental studies. The results obtained from the experimental studies showed that the fuel properties of biodiesel produced from these feedstocks meet the ASTM biodiesel standards and are comparable to those of the regular petroleum diesel fuels. Gunawan et al. [35] assessed the potential of Rice bran for biodiesel production. Due to the fact that the price of Rice bran is a low, it has good potential to be used as biofuel. In this research, the effect of various parameters, such as the molar ratio of methanol to rice bran, catalyst amount and reaction time on the biodiesel produced from rice bran, was investigated. Sulfuric acid was used as the catalyst. The results showed that when the molar ratio of methanol to rice bran ratio is $5 \mathrm{~mL} / \mathrm{g}$, the concentration of sulfuric acid in methanol is $1.5 \%$ and the reaction time is $60 \mathrm{~min}$, the highest rate of rice bran conversion to biodiesel will be obtained. Zanuttini et al. [36] investigated the kinetics of esterification relating to the process of biodiesel production from Butia Yataycoconut oil. Considering the fact that the acid value of Butia Yataycoconut oil was high (between 109 and $140 \mathrm{mg} \mathrm{KOH} / \mathrm{g}$ ), esterification of free fatty acids was performed at the first step. Results of the kinetic parameters of esterification showed that there is a significant difference between the acid composition of Butia Yataycoconut oil and other oils, including sunflower oil. Hajinezhad et al. [37] studied the properties of biodiesel production from Norouzak (Salvia lerifolia) seeds in 2015. In their research, the biodiesel production process was performed using ultrasound technology. In order to carry out the transesterification reaction, potassium hydroxide was used as a catalyst at a concentration of $1 \mathrm{wt} \%$ and the reaction temperature was considered to be $40^{\circ} \mathrm{C}$. The results of the experiment showed that methanol to oil molar ratio has the highest effect on the performance of methyl ester production, such that when the methanol molar ratio is equal to 1:6, the highest rate of conversion of Norouzak (Salvia lerifolia) seeds to methyl ester $(97.6 \%)$ is achieved. The physical and chemical properties showed that the biodiesel produced from Norouzak (Salvia lerifolia) seeds meets the requirements of EN 14124 standards. Tin Ang et al. [38], using Response surface methodology (RSM) analysis, optimized various variables (reaction temperature, reaction time, molar ratio of methanol to oil) in order to achieve the highest biodiesel content. Results showed that at the optimal condition the biodiesel content is 78\%. Kakati and Gogoi [39] studied the physical and chemical characteristics of oil and biodiesel of Kutkura (Meyna spinosa Roxb Ex.) seed oil. The amount of Kutkura (Meyna spinosa Roxb.) oil content was about 34\%. The results of the study of physical and chemical properties of biodiesel produced from Kutkura (Meyna spinosa Roxb.) showed that the measured properties meet the limits of ASTM D6751 and EN14214 standards. Ijaz et al. [40] studied the biodiesel from produced Ricinus communis L. Oil in terms of physical and chemical properties. Potassium hydroxide was used as the catalyst for transesterification reaction. Investigation of various variables showed that the optimal conditions for biodiesel production were as follows: methanol $/$ oil molar ratio $=6: 1$, reaction temperature $=60{ }^{\circ} \mathrm{C}$, reaction time $=45 \mathrm{~min}$ and catalyst amount $=0.32 \mathrm{~g}$. Results of qualitative evaluation showed that the physical and chemical properties of biodiesel produced from Ricinus communis L. Oil is consistent with the requirements of ASTM standards. Soukht Saraee et al. [41] studied the physical and chemical characteristics of the biodiesel produced from Pistacia Khinjuk. The oil content obtained from Pistacia Khinjuk seed was reported to be $35-40 \%$. The results showed that the physicochemical properties of the biodiesel of pistacia (Pistacia Khinjuk) oil seed meet the ASTM standard. Recently, many studies have been conducted on different cultivars of camelina sativa for biodiesel production. In Table 1, a number of studies are reviewed. 
Table 1. A number of studies about biodiesel of different cultivar of camelina sativa.

\begin{tabular}{|c|c|c|c|}
\hline Reference & Raw Material & Biodiesel Properties & $\begin{array}{l}\text { Effect of Biodiesel on Performance and Emission of Diesel } \\
\text { Engine }\end{array}$ \\
\hline [42] & Camelina sativa (camelina) & $\begin{array}{l}\text { The methyl ester produced from camelina oil has properties similar to } \\
\text { rape methyl ester, with the exception of its higher iodine value. }\end{array}$ & $\begin{array}{l}\text { Fuel consumption and general vehicle operation with camelina ester } \\
\text { are similar to what one would expect from rape methyl ester. }\end{array}$ \\
\hline [43] & Camelina sativa seed oil & $\begin{array}{l}\text { Accelerated thermal ageing tests on the camelina oil suggest that } \\
\text { Camelina oil is susceptible to oxidation with significant reduction in } \\
\text { degree of unsaturation and corresponding increase in viscosity. }\end{array}$ & $\begin{array}{l}\text { - Camelina oil produced a maximum power at the road wheels } \\
\text { of } 43.25 \mathrm{~kW} \text { and returned } 12.57 \mathrm{~km} / \mathrm{L} \text { compared to } 38.50 \mathrm{~kW} \\
\text { and } 14.03 \mathrm{~km} / \mathrm{L} \text { for the mineral fuel. } \\
\text { both smoke opacity and CO with camelina biodiesel was found } \\
\text { to be approximately } 50 \% \text { lower than with the mineral fuel } \\
\text { - NO was higher for the camelina biodiesel by almost } 6 \% \text { than } \\
\text { mineral fuel at engine speeds }>3500 \mathrm{rpm}\end{array}$ \\
\hline
\end{tabular}

- The composition of camelina sativa oil, especially high content of linolenic acid that makes this oil particularly susceptible to oxidation,

- More emission with camelina biodiesel was found to be lower

- Camelina sativa oil has a high density. than with the diesel fuel

- The kinematic viscosity, Acid Value, lubricity, sulfur and

phosphorous contents, as well as the surface tensions of camelina

biodiesel were satisfactory according to ASTM D6751 and

Not described

[45] Camelina sativa oil EN 14214

- Most fuel properties such as kinematic viscosity, acid number flash point, sulfur content, total glycerol content. Its cetane number (49.7) was satisfactory according to ASTM D675 
The literature review of the biodiesel resource revealed that seed oil can be used as biodiesel [21,47-49]. In the present study, Camelina "Soheil" seed oil was studied for biodiesel production. Camelina "Soheil" grows in areas with lower fertility, requires less irrigation and fertilization, and produces seeds that can produce large amounts of oil. So Camelina "Soheil" is capable of growing in different regions of Iran. The objective of the present study is to investigate the feasibility of biodiesel production from Camelina "Soheil" seed using ultrasonic system and optimize the process of biodiesel production by the response surface methodology (RSM). Also, the effect of Camelina "Soheil" biodiesel on performance and emissions parameters of diesel engine was investigated.

\section{Materials and Methods}

\subsection{Materials}

The Camelina "Soheil cultivar" is a member of the Brassicaceae family. The water requirement of "Soheil" is low, and it has more resistance to frost than other plants. "Soheil cultivar" grows in areas with lower fertility, and requires less fertilization, so Camelina "Soheil" is capable of growing in most regions of Iran [50]. Firstly, ripe seeds of Camelina "Soheil cultivar" were collected from a Farm located in Kordan (between Karaj and Qazvin) and seeds were extracted after drying of the stems.

In this research, potassium hydroxide $(\mathrm{KOH})$ and Methanol of analytical grades were obtained from Sigma Aldrich Chemical Suppliers, Tehran, Iran. An ultrasonic device (Hielscher Model UP400S, USA), that equipment has been sourced from FARASOUT SANAT Eng CO, Tehran, Iran, was employed in order to perform biodiesel production (transesterification reaction). The equipment consists of a processor, sonotrode, and PC controller. The ultrasonic set-up is shown in Figure 1. The employed ultrasonic was operated at $400 \mathrm{~W}$ and $24 \mathrm{kHz}$ frequency.

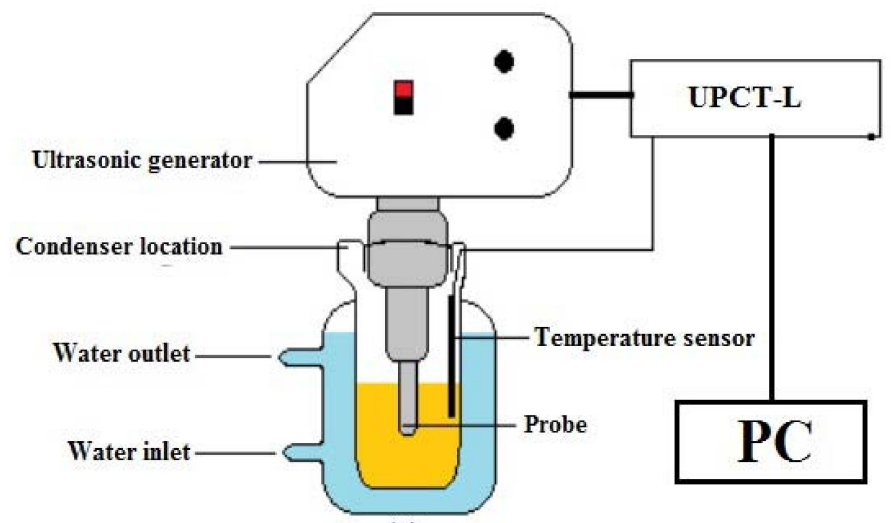

(a)

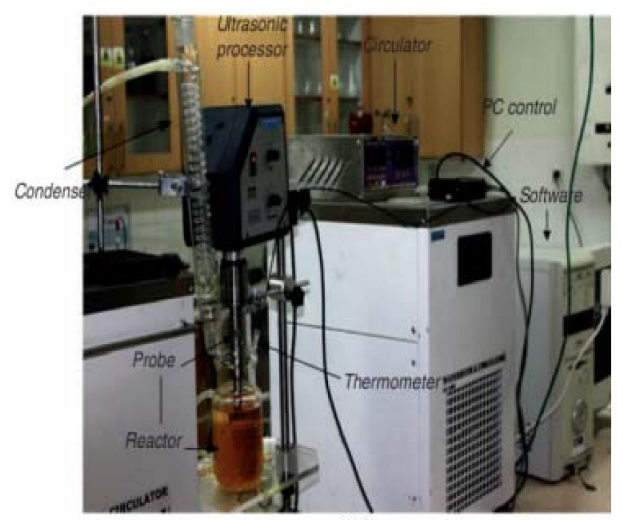

(b)

Figure 1. Ultrasonic-assisted biodiesel production process: (a) schematic, (b) apparatus.

\subsection{Oil Extraction Process and Determination of Oil Content}

After separating the seeds of "Soheil" from the stems, $6 \mathrm{~g}$ of "Soheil" seeds were crushed in a grinder. Then the crushed seeds were placed inside a filter paper. Filter papers containing "Soheil" crushed seeds were placed in the Soxhlet extraction system, which was filled with n-Hexane, and the oil extraction started. $200 \mathrm{~mL}$ of n-Hexane was used as solvent in the Soxhlet system. After $5 \mathrm{~h}$, filter papers containing "Soheil" seed were placed at ambient temperature for $24 \mathrm{~h}$ to dry. The oil content was determined exactly using Equation (1) [51].

$$
\operatorname{Oilcontent}(\%)=\frac{\left(P_{1}-P_{2}\right)}{P} \times 100
$$


where $P_{1}$ is the weight of filter paper containing "Soheil" crushed seeds before oil extraction, $P_{2}$ is the weight of the filter paper containing "Soheil" crushed seeds after drying, and $P$ is the weight of the crushed "Soheil" seeds.

\subsection{Determination of Fatty Acid Composition (FAC)}

In this research, the Metcalfe method [52] was used to investigate the structure of the fatty acids. Fatty acid composition (FAC) of "Soheil" oil (CSO) was determined at the Institute of Renewable Energy, Tarbiat modares University, Tehran, Iran using gas chromatography (Clarus 580 GC). Determination of fatty acid composition steps are as follows: (step 1) weigh CSO oil (about $50 \mathrm{mg}$ ) and $\mathrm{NaOH}$ solution $(2 \%)$ in methanol $(5 \mathrm{~mL})$, then add to the test tube. (Step 2) place the solution in a water bath at $100{ }^{\circ} \mathrm{C}$ for ten minutes. (Step 3) remove the test tube from the water bath. Cool to room temperature. (Step 4) add $2.175 \mathrm{~mL}$ of BF3 $20 \%$ to the solution and place in a water bath at $100{ }^{\circ} \mathrm{C}$ for $3 \mathrm{~min}$. (Step 5) remove the test tube from the water bath. Cool to room temperature. (Step 6) add $1 \mathrm{~mL}$ of $\mathrm{n}$-heptane to the solution then shake the solution by centrifuge. (Step 7) add $1 \mathrm{~mL}$ of saturated $\mathrm{NaCl}$ salt acid to the solution in order to separate the organic phase containing methyl esters of fatty acids then shake the solution by centrifuge. (Step 8) transfer the separated Fatty acid phase into an autosampler vial for GC analysis. Gas chromatography (Clarus 580 GC) was used to determine the fatty acid composition.

\subsection{Transesterification Process}

Prior to the transesterification reaction, the acid value has to be measured. Therefore, in this study, the content of free fatty acid (FFA) of CSO was determined using titration. Using the Van Gerpen et al. [53] method, the acid value of CSO was calculated. The results showed that acid value of CSO was less than $1 \%$. Therefore, due to the low value of the acid number, the acid-catalyzed esterification step was not necessary and the transesterification reaction was performed directly. To carry out the transesterification reaction, methanol and potassium hydroxide were mixed by magnetic stirrer for $4 \mathrm{~min}$ to produce methoxide. The produced methoxide mixture was mixed with CSO in a conical flask. The mixture of potassium methoxide-CSO was then transferred to a reaction chamber to be exposed to ultrasonic waves. Pulse, amplitude and reaction time were adjusted by the controller. In order to carry out the transesterification reaction, the temperature, amplitude and pulse were considered as $50{ }^{\circ} \mathrm{C}, 70 \%$ and 70 , respectively. The effect of different variables including reaction time, molar ratio (methanol to oil), and catalyst concentration on the rate of Camelina "Soheil" oil (CSO) conversion to methyl ester was studied. After the reaction, a two-phase product was generated with the upper phase being biodiesel, and the lower being glycerol. After separating the glycerol, biodiesel was purified (In order to purify the biodiesel, the biodiesel was washed by water three times). Using gas chromatography (Clarus $580 \mathrm{GC}$ ), the fatty acid composition of biodiesel was determined and the biodiesel yield (rate of CSO conversion to methyl ester) was calculated.

\subsection{Characterization of Fuel Properties of Biodiesel from "Soheil" Oil (CSO)}

After purifying the produced biodiesel, the physical and chemical properties of CSO were evaluated based on the ASTM biodiesel standard. Physical and chemical characteristics include: Density at $15{ }^{\circ} \mathrm{C}$ (ASTM D4052), Kinematic viscosity at $40{ }^{\circ} \mathrm{C}$ (ASTM D445), Cloud point (ASTM D6751), Pour point (ASTM D6751), Flash point (ASTM D93), Iodine value (AOAC CD1-25), Acid value (ASTM D664), Oxidation stability, $110{ }^{\circ} \mathrm{C}$ (EN 14112), Cetane number (ASTM D613), Total glycerin (ASTM D6584), ash content (ASTM D874), Free glycerin (ASTM D6584) and Sulfur content (ASTM D5459).

\subsection{Statistical Analysis (Statistical Optimization by RSM)}

In this research, a 3-levels-3-factor Box-Behnken design was used to investigate the effect of independent variables on the reaction yield of fatty acid methyl esters (FAME). Independent variables included the molar ratio of methanol to oil, pulse, amplitude, and reaction time. 12 factorial points 
were considered for the Box-Behnken factorial design used in this study. 5 central points were also considered for fitting a second-order response surface. In Table 2, the test matrix is shown, along with the used independent variables. It is noteworthy that Design-Expert ${ }^{\circledR}$ Software (version 7) was employed for statistical analysis, and optimization was performed using the response surface methodology (RSM) to achieve the highest reaction yield of FAME.

Table 2. Range of ANVOA.

\begin{tabular}{ccccc}
\hline Independent Variables & Symbols & \multicolumn{3}{c}{ Levels of Each Factor } \\
\hline Catalyst concentration (wt \%) & $\mathrm{A}$ & 1 & 1.5 & 2 \\
Molar ratio (alcohol to oil) & $\mathrm{B}$ & $2: 1$ & $7: 1$ & $12: 1$ \\
Reaction time (min) & $\mathrm{C}$ & 2 & 6 & 10 \\
\hline
\end{tabular}

\subsection{Engine Test}

In the present study, an air-cooled single-cylinder engine (Lombardini DIESEL 3LD 510) was used. (Figure 2) that equipment has been sourced from Diesel Niro CO, Tehran, Iran. The specifications of the diesel engine are shown in Table 3. In order to control the load, torque, and speed of the engine, an eddy current dynamometer model WE400 was employed. The AVL DITEST GAS 1000 Emission Analyzer was used to determine the emissions ( $\mathrm{CO}, \mathrm{UHC}, \mathrm{CO}_{2}$, and $\mathrm{NOx}$ ) of the diesel engine. The emission parameters and performance of the engine running on biodiesel (derived from Camelina "Soheil" oil) and blended with diesel fuel, namely B10 and B20, were evaluated and compared with diesel fuel (B0). All the experiments were performed under a constant speed of $2100 \mathrm{rpm}$ at loads of $0 \%, 25 \%, 50 \%, 75 \%$, and $100 \%$.
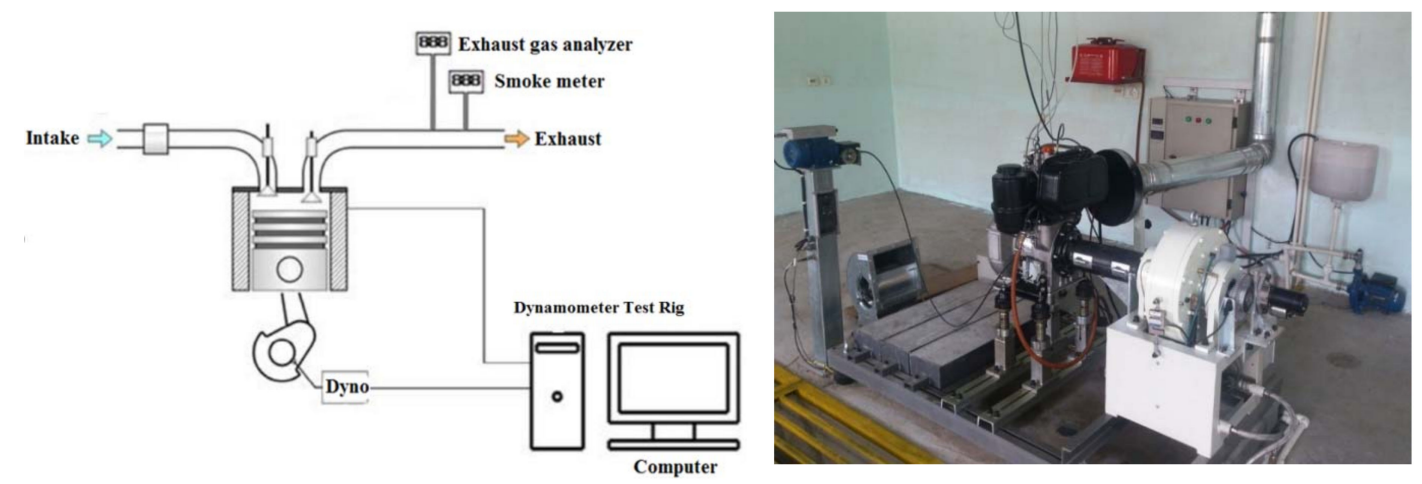

Figure 2. Engine test set-up and test instruments.

Table 3. Specifications of diesel engine.

\begin{tabular}{cc}
\hline Technical Spec. & \\
\hline Model & 3LD 510, Battipaglia-Salerno-ITALY \\
No. of cylinder & 1 \\
Bore $\times$ Stroke $(\mathrm{mm})$ & $85 \times 90$ \\
Cyl. Vol. $\left(\mathrm{cm}^{3}\right)$ & 510 \\
Comp. Ratio & $17.5: 1$ \\
Max. Power $(\mathrm{kW})$ & 9 \\
Max. Torque $(\mathrm{Nm}) @ 1800 \mathrm{rpm}$ & 33 \\
\hline
\end{tabular}

\subsection{Uncertainties Analysis}

Uncertainties in the experiments may occur due to the choice of instrument, working conditions, calibration, environment, observation and method of implementation of the tests $[54,55]$. By using the root-sum-square method, the percentage uncertainties in measuring various parameters were 
determined [55]. In Table 4, the percentage uncertainties of various instruments used in the experimental investigation are shown.

Table 4. Percentage uncertainties of various instruments.

\begin{tabular}{|c|c|c|c|}
\hline Instruments & Measuring Range & Accuracy & $\begin{array}{c}\text { Percentage } \\
\text { Uncertainties }\end{array}$ \\
\hline \multirow[t]{5}{*}{ AVL DITEST GAS 1000} & CO $0-15 \%$ vol. & $\begin{array}{c}<10.0 \% \text { vol.: } \pm 0.02 \% \text { vol., } \pm 3 \% \\
\text { o.M. } \geq 10.0 \% \text { vol: } \pm 5 \% \text { o. M. }\end{array}$ & \pm 0.3 \\
\hline & $\mathrm{CO}_{2} 0-20 \%$ vol. & $\begin{array}{l}<16.0 \% \text { vol.: } \pm 0,3 \% \text { vol., } \pm 3 \% \\
\text { o.M. } \geq 16.0 \% \text { vol: } \pm 5 \% \text { o. } \mathrm{M} .\end{array}$ & \pm 0.2 \\
\hline & HC 0-30,000 ppm vol. & $\begin{array}{c}<2000 \text { ppm vol.: } \pm 4 \text { ppm vol., } \pm 3 \% \\
\text { o.M. } \geq 5000 \text { ppm vol.: } \pm 5 \% \text { o. } \\
\text { M. } \geq 10,000 \text { ppm vol.: } \pm 10 \% \text { o. M }\end{array}$ & \pm 0.2 \\
\hline & $\mathrm{O}_{2} 0-25 \%$ vol. & $\pm 0.02 \%$ vol. $\pm 1 \%$ o.M. & \pm 0.3 \\
\hline & $\mathrm{NO}_{x}$ 0-5000 ppm vol. & \pm 5 ppm vol. $\pm 1 \%$ o. M. & \pm 0.2 \\
\hline
\end{tabular}

\section{Result and Discussion}

\subsection{Characterization of the Camelina "Soheil" Oil (CSO)}

Using the Soxhlet extraction method, the amount of oil extracted from CSO was reported to be $29 \%$. The amount of the extracted oil indicates that "Soheil" has a higher oil content compared to many oily seeds [56]. After oil extraction, oil properties were identified using gas chromatography (Clarus 580 GC). Table 5 shows the physical and chemical properties of CSO. Kinematic viscosity of CSO is relatively low. Probably because of the high content of linolenic acid (23.01\%), the kinematic viscosity of CSO is low. So this feature is an important property of this new feedstock in biodiesel production.

Table 5. Chemical and physical properties of the used CSO.

\begin{tabular}{ccc}
\hline Properties & Units & Measured Property \\
\hline Density & $\mathrm{g} / \mathrm{cm}^{3}$ & 0.92 \\
Kinematic viscosity & $\mathrm{mPa} \cdot \mathrm{s}$ & 33 \\
Acid value & $\mathrm{Mg} \mathrm{KOH} / \mathrm{g}$ & 0.89 \\
Water content & $\mathrm{oil}$ & 0.10 \\
Palmitic acid (C16:0) & $\mathrm{mg} / \mathrm{g} \%$ & 4.53 \\
Stearic acid (C18:0) & $\mathrm{wt} \%$ & 1.94 \\
Oleic acid (C18:1)* & $\mathrm{wt} \%$ & 11.12 \\
Linoleic acid (C18:2) & $\mathrm{wt} \%$ & 15.15 \\
Linolenic acid (C18:3)* & $\mathrm{wt} \%$ & 23.01 \\
Other fatty acids & $\mathrm{wt} \%$ & 44.25 \\
\hline
\end{tabular}

\subsection{Statistical Analysis}

The first proposed model by the Design-Expert ${ }^{\circledR}$ Software was the polynomial quadratic model, and the analysis was performed based on this model. The proposed model based on Analysis of Variance (ANOVA) is shown in Equation (2).

$$
\begin{aligned}
& \text { Conversion }(\%)=68.04246+3.38036 \times A+7.67297 * B-3.75617 * \mathrm{C}-1.49131 * \mathrm{~A} * \mathrm{~B} \\
& +2.25024 * \mathrm{~A} * \mathrm{C}+0.19561 * \mathrm{~B} * \mathrm{C}-5.48508 * \mathrm{~A} 2-0.31950 * \mathrm{~B} 2-4.36231 \times 10^{-4} \times \mathrm{C} 2
\end{aligned}
$$

where A is Catalyst concentration (wt \%), B is molar ratio (methanol to oil) and $\mathrm{C}$ is reaction time (min). Table 6 shows the proposed model by RSM. Also, in Table 7, the results of variance analysis of 
the RSM model are shown based on ANOVA analysis. The probability value (p-value) for the model is less than 0.01 . Therefore, ANOVA shows that the model is statistically significant. The catalyst concentration ( $\mathrm{wt} \%$ ), molar ratio (methanol to oil) and reaction time $(\mathrm{min})$ have a significant effect on biodiesel yield. Also, the interaction of the catalyst concentration ( $\mathrm{wt} \%)$-reaction time (min) and interaction of the molar ratio (methanol to oil)—reaction time ( $\mathrm{min}$ ) are significant.

Table 6. Quadratic model statistics.

\begin{tabular}{cccccccc}
\hline Statistical Model & Std. Dev. & $\mathbf{C V} \%$ & $\mathbf{R}^{\mathbf{2}}$ & Adjusted $\mathbf{R}^{\mathbf{2}}$ & Predicted $\mathbf{R}^{\mathbf{2}}$ & PRESS & \\
\hline Linear & 6.52 & 7.78 & 0.6662 & 0.5828 & 0.3431 & 1002.89 & \\
2FI & 5.36 & 6.4 & 0.8308 & 0.7180 & 0.1991 & 1222.48 & \\
Quadratic & 2.26 & 2.69 & 0.98 & 0.95 & N/A & N/A & Suggested \\
Cubic & 2.24 & 2.67 & 0.9869 & 0.9508 & N/A & N/A & Aliased \\
\hline
\end{tabular}

Table 7. Analysis of variance (ANOVA) for response surface methodology (RSM) model.

\begin{tabular}{cccccc}
\hline Source & Sum of Squares & df & Mean-Square & F-Value & $p$-Value \\
\hline Model & 1496.219 & 9 & 166.2466 & 32.66114 & 0.0002 \\
A-Catalyst concentration (wt \%) & 133.6698 & 1 & 133.6698 & 26.26103 & 0.0022 \\
B-molar ratio (methanol to oil) & 608.7634 & 1 & 608.7634 & 119.5989 & $<0.0001$ \\
C-reaction time (min) & 123.7505 & 1 & 123.7505 & 24.31228 & 0.0026 \\
AB & 27.80006 & 1 & 27.80006 & 5.461656 & 0.0581 \\
AC & 81.01741 & 1 & 81.01741 & 15.91684 & 0.0072 \\
BC & 61.22434 & 1 & 61.22434 & 12.02826 & 0.0133 \\
A $^{2}$ & 6.267942 & 1 & 6.267942 & 1.231413 & 0.3096 \\
B $^{2}$ & 212.6612 & 1 & 212.6612 & 41.77985 & 0.0007 \\
C $^{2}$ & 0.000162 & 1 & 0.000162 & $3.19 \times 10^{-5}$ & 0.9957 \\
Residual & 30.54025 & 6 & 5.090042 & & \\
Lack of Fit & 10.51385 & 2 & 5.256923 & 1.049998 & 0.4300 \\
Pure Error & 20.02641 & 4 & 5.006602 & & \\
Std. Dev. & 2.26 & & & & \\
C.V\% & 2.69 & & & & \\
\hline
\end{tabular}

\subsection{Effects of Reaction Parameters on the Transesterification Process (Biodiesel Yield)}

\subsubsection{Molar Ratio (Methanol to Oil)—Reaction Time}

One of the important factors in biodiesel production is investigating the molar ratio of methanol to oil. Methanol plays a fundamental role in biodiesel conversion. The amount of methanol added to a crude oil causes the large branched molecules of vegetable oils break down into smaller linear methyl ester oils. In the other words, the methanol requires transesterification of triglycerols into fatty acid methyl esters $[57,58]$. In this study, the effect of molar ratios of methanol to CSO, ranging from 2:1 to 12:1, on the rate of biodiesel conversion was studied. As observed in Figure 3, three different mass ratios of methanol to oil molar ratio were tested; 2:1, 7:1, and 12:1. The methyl ester content was increased as the molar ratio of methanol to oil was raised from 2:1 to 10:1. However, further increase to 12:1 had negative effects on methyl ester conversion. Too much methanol could dilute the oil and as a result slow the reaction rate [59]. Another parameter that has an important effect on biodiesel production process is reaction time. The dependency of reaction time was studied at three different time intervals ranging from $2-10 \mathrm{~min}$. The optimum conversion of $98.21 \%$ was observed at $10 \mathrm{~min}$ when the concentration of catalyst is 1.5 (wt \%). The reaction time has a significant effect ( $p$-value $<0.05$ ) on biodiesel conversion. The interaction of the molar ratio (methanol to oil)-reaction time has a significant $(p$-value $<0.05)$ effect on biodiesel conversion. 


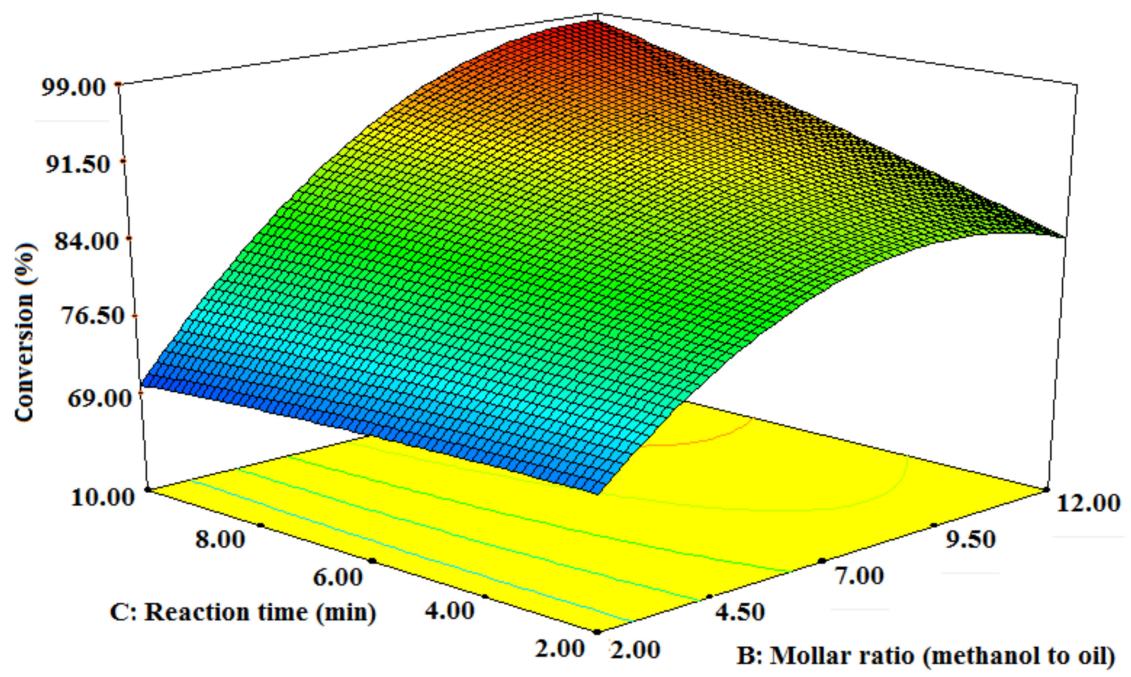

Figure 3. Effect of molar ratio (methanol to oil)-reaction time on biodiesel yield (\%) when catalyst concentration (wt \%) is equal to 1.5 .

\subsubsection{Reaction Time (min)—Catalyst Concentration (wt \%)}

In general, by reviewing previous research, it was observed that depending on the type of oil used, catalyst concentration of less than or equal to $1 \%$ is required for a successful conversion of oils to fatty acid methyl ester [60]. In this research, the effect of catalyst concentration on biodiesel conversion in the range $1 \mathrm{wt} \%$ to $2 \mathrm{wt} \%$ was studied. As shown in Figure 4, the $1.0 \%$ concentration of catalyst is an optimal point to achieve higher conversion. With the addition of an excess amount of catalyst (greater than $1 \mathrm{wt} \%$ ) the methyl ester conversion decreases. At higher catalyst concentrations, biodiesel-glycerol emulsion results in the separation of glycerol from the biodiesel becoming difficult. The results of ANOVA in Table 7 show that catalyst concentration ( $w t \%)$ has a significant effect (at the level of 0.05 ) on biodiesel conversion. The interaction of the catalyst concentration with reaction time has a significant effect $(p$-value $<0.01)$ on methyl ester conversion.

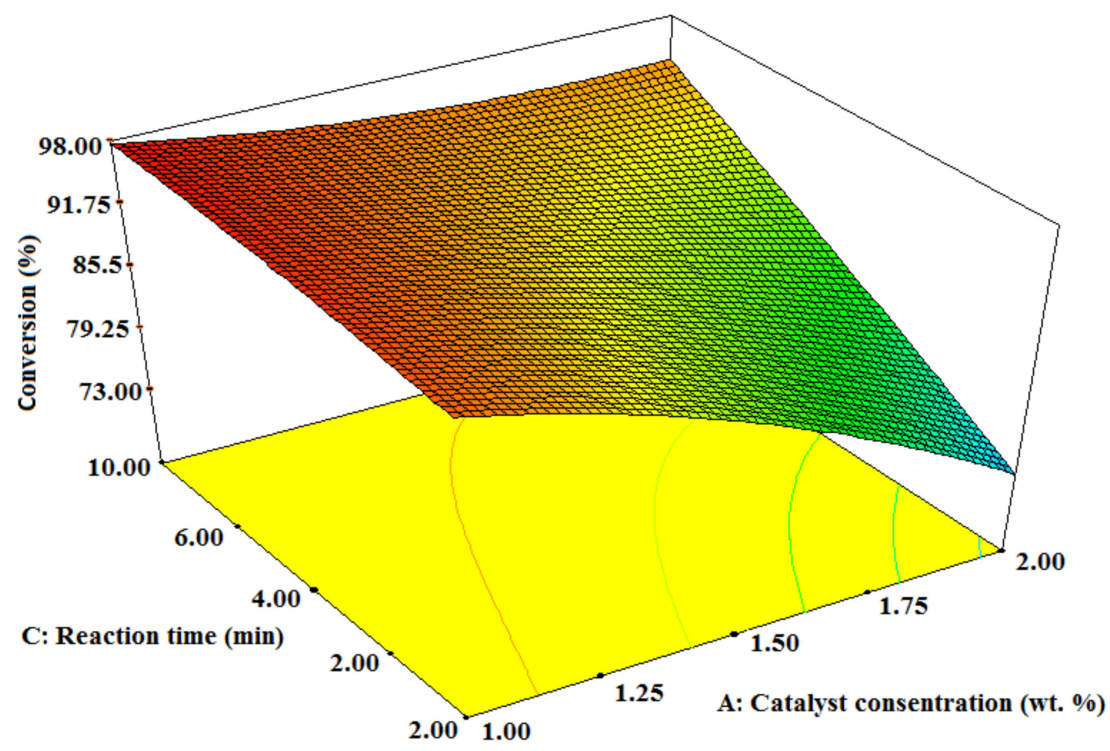

Figure 4. Catalyst concentration (wt \%)-reaction time (min) on biodiesel conversion (\%) when methanol to oil molar ratio equal to 8.11 . 


\subsection{Optimization Process Using Response Surface Methodology (RSM)}

The optimal value for each of the studied variables was predicted by Equation (2) in order to obtain the highest rate of biodiesel conversion. Equation (2) is based on the polynomial regression equation, which is derived from the response surface methodology (RSM) model. The optimal value for each of the variables is as follows: molar ratio (methanol to oil) equal to 10.18:1; reaction time of $7.33 \mathrm{~min}$; and catalyst concentration of $1.15 \mathrm{wt} \%$. The polynomial regression equation predicted that if the variables acquire these values, the highest rate of biodiesel conversion $(99.51 \%)$ will be obtained. In order to verify the predicted value, the optimized variables were experimentally studied. The experimental test showed biodiesel conversion equal $98.91 \%$. The biodiesel conversion predicted by response surface methodology (RSM) is in excellent agreement with the experimental measurements.

\subsection{Characterization and Properties of "Soheil" Biodiesel}

The properties of the produced biodiesel are among the most important topics to consider in the study of new fuels. The newly produced fuel must be able to meet existing standards in terms of physical and chemical properties. In this study, many properties of the biodiesel produced from CSO were determined. Table 8 shows the properties of biodiesel produced from CSO.

Density has a direct impact on the injection performance of the fuel and influences fluid movement inside the pipelines, injector nozzles and orifices [61-63]. The density of "Soheil" methyl ester (AAMEs) is $883 \mathrm{~kg} / \mathrm{m}^{3}$. The density of AAMEs is within the range of the ASTM D4052 standard. The density of AAMEs is higher than the density of some conventional biodiesels, including soybean $\left(0.883 \mathrm{~g} / \mathrm{cm}^{3}\right)$ [64], canola $\left(0.882 \mathrm{~g} / \mathrm{cm}^{3}\right)$ [65], sunflower $\left(0.880 \mathrm{~g} / \mathrm{cm}^{3}\right)$ [65]. One of the important features of biodiesel is its kinematic viscosity. Viscosity determines the level of the fuel fluidity and plays a vital role in combustion and in the formation of deposits and soot. If the viscosity is high, complete combustion will not take place, and atomization capability of the fuel will be weakened [66]. The results of the study showed that the viscosity of the AAMEs is $4.01 \mathrm{~mm}^{2} / \mathrm{s}$. The viscosity of AAMEs is consistent with the requirements of the ASTMD445 standard. The viscosity of AAMEs is lower compared to conventional biodiesels such as palm $\left(5.7 \mathrm{~mm}^{2} / \mathrm{s}\right)$ [65] and castor $\left(15.25 \mathrm{~mm}^{2} / \mathrm{s}\right)$ [65]. A low viscosity is an advantage for AAMEs since it facilitates the fuel flow inside the engine.

Another important characteristic of the fuel is cloud point. Cloud point is the temperature at which a cloud or a halo of crystals of paraffinic compounds appears inside the fuel (at this temperature, the sample does not lose its fluidity and is usable). The cloud point is an important fuel characteristic for low-temperature applications, and lower values of cloud point are more desirable. According to Table 8 , it is evident that the cloud point of AAMEs is $-2{ }^{\circ} \mathrm{C}$, which meets the requirements of ASTM D6751. Pour point is another important characteristic of biodiesel fuel. Pour point is the lowest temperature at which an oil specimen can flow. The pour point temperature is lower than the cloud point temperature. According to the results, the pour point of AAMEs is $-6{ }^{\circ} \mathrm{C}$, which is consistent with ASTM D6751 standard. Another parameter with significant impact on combustion is the flash point. Flash point is the lowest temperature at which the vapor of the fuel starts to burn. Fuels with a high flash point reduce the risk of fire [67]. The flash point of AAMEs is $154{ }^{\circ} \mathrm{C}$, which meets the ASTM D93 standard. One of the advantages of biodiesel in comparison to diesel is the high value of the flash point in biodiesel fuel [56]. Cetane number is an important parameter in fuel, which plays a significant role in combustion inside diesel engines. The cetane number of each fuel indicates whether combustion is carried out simply or vice versa. The cetane number has a significant effect on the parameters of diesel engine relating to combustion, performance and pollution [68,69]. According to Table 8 , it is found that the AAMEs' cetane number is 46 , which meets the requirements of the ASTM D613 standard. In general, the cetane number of biodiesel fuel is greater than diesel; therefore, the efficiency of biodiesel combustion is higher than diesel. The results of measurement of other characteristics of biodiesel produced from "Soheil" oil are shown in Table 8. All of the characteristics of the produced biodiesel are consistent with the requirements of the ASTM D6751 standard. 
Table 8. The produced biodiesel properties in comparison with the ASTM D6751 standard.

\begin{tabular}{ccccc}
\hline Property & Test Method & Limits & Units & Measured Property \\
\hline Water and Sediment & ASTM D2709 & $0.05 \mathrm{max}$ & $\%$ volume & $<0.004$ \\
Density at $15{ }^{\circ} \mathrm{C}$ & ASTM D4052 & $0.86-0.90$ & $\mathrm{~g} / \mathrm{cm}^{3}$ & 0.883 \\
Kinematic Viscosity @ $40{ }^{\circ} \mathrm{C}$ & ASTM D445 & $1.9-6.0$ & $\mathrm{~mm}^{2} / \mathrm{s}$ & 4.01 \\
Methanol Content & EN 14110 & $0.20 \mathrm{max}$ & $\%$ volume & $0<0.01$ \\
Flash Point, Closed Cup & D93 & $130 \mathrm{~min}$ & ${ }^{\circ} \mathrm{C}$ & 154 \\
Cloud point & ASTM D6751 & -3 to 12 & ${ }^{\circ} \mathrm{C}$ & -2 \\
Pour point & ASTM D6751 & -15 to 10 & ${ }^{\circ} \mathrm{C}$ & -6 \\
Cetane Number & ASTM D613 & - & & 46 \\
Carbon Residue & ASTM D4530 & 0.05 max & $\%$ mass & 0.02 \\
Acid Number & ASTM D664 & 0.50 max & mg & 0.27 \\
Total Glycerin & ASTM D6584 & 0.24 & $\% \mathrm{~g}$ & 0.175 \\
\hline
\end{tabular}

\subsection{Engine Performance}

\subsubsection{Engine Brake Power}

Power is defined as the rate of work done by the engine. Specifications of biodiesel, especially in heating value, lubricity, and viscosity have an important effect on engine power. By using the high concentration rate of biodiesel, the engine brake power (BP) increases. The improvement in engine power can be attributed to the increase in the indicated mean effective pressure for higher biodiesel concentration [70]. The heat evaporation of biodiesel fuel is higher than diesel fuel; this characteristic provides fuel-air charge cooling and increases the density of the charge. Thus, higher power output is obtained [71]. The variation of BP with diesel-biodiesel fuels is shown in Figure 5. Improvement in $\mathrm{BP}$ is observed with the increase of biodiesel concentration. The highest BP is observed for B20 at the full load.

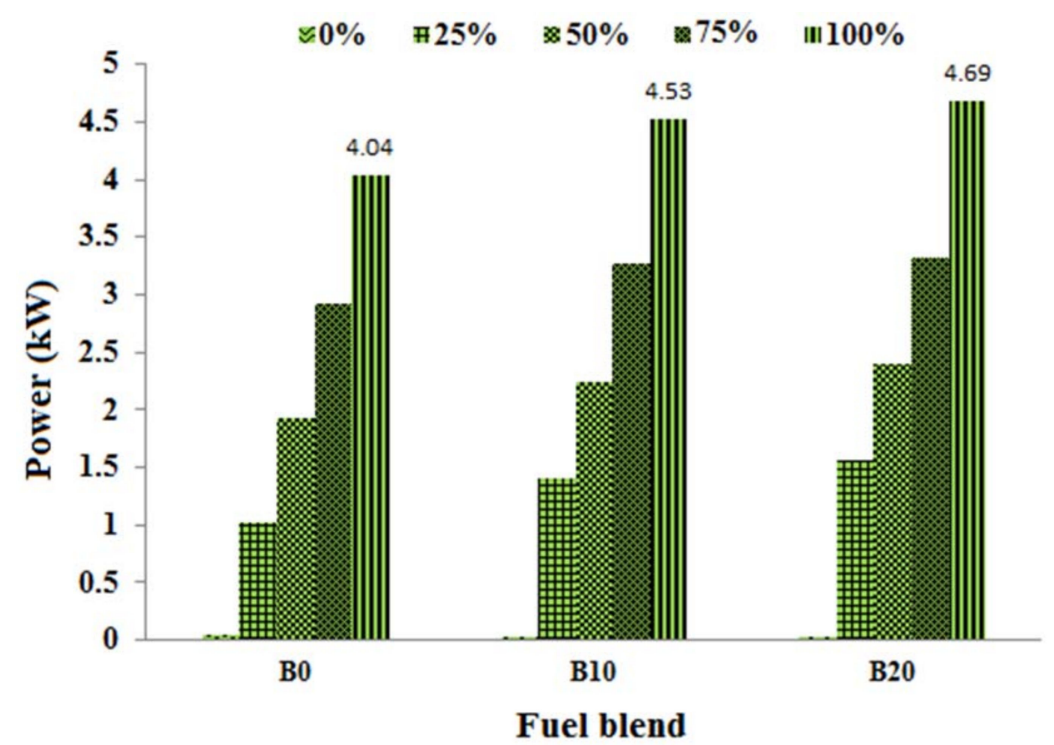

Figure 5. Results of brake power for different fuel blends at a constant speed of $2100 \mathrm{rpm}$.

\subsubsection{Specific Fuel Consumption (SFC)}

The specific fuel consumption (SFC) for all fuel blends in full load operating condition shown in Figure 6. The specific fuel consumption of the diesel-biodiesel blends is lower than pure diesel fuel. This phenomenon is due to the result of biodiesel addition, which promotes combustion [72]. The lowest SFC observed as $355.34 \mathrm{~g} / \mathrm{kW} \cdot \mathrm{h}$ for the B20 blend, whereas it is $415 \mathrm{~g} / \mathrm{kW} \cdot \mathrm{h}$ for neat diesel (Figure 6). 


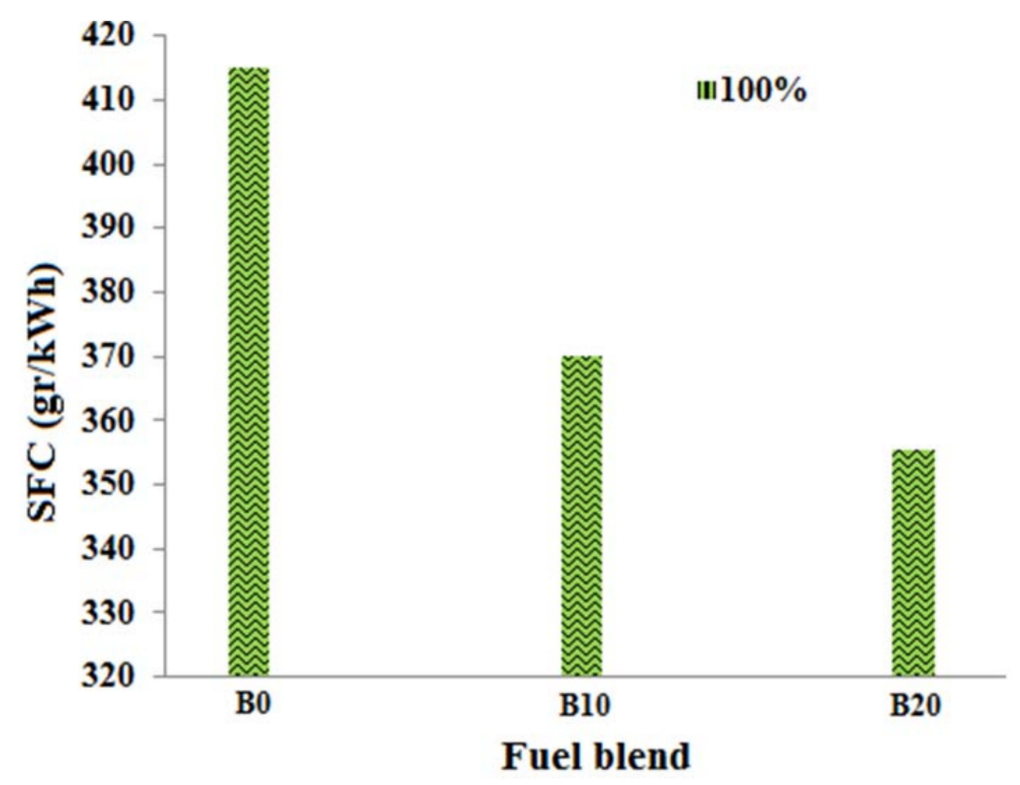

Figure 6. Results of specific fuel consumption (SFC) for different fuel blends at the constant speed of $2100 \mathrm{rpm}$.

\subsection{Engine Emissions}

\subsubsection{Carbon Monoxide (CO)}

The variations of carbon monoxide (CO) for various fuel blends are shown in Figure 7. The CO emission of biodiesel blends include of B10 and B20 was lower than diesel. The low $\mathrm{CO}$ emission of biodiesel relative to diesel is due to the high cetane number of biodiesel [55], because biodiesel-diesel blends contain some extra oxygen in their molecules. Therefore, the oxygen contained in the fuel enhances complete combustion in the cylinder and reduces $\mathrm{CO}$ emission.

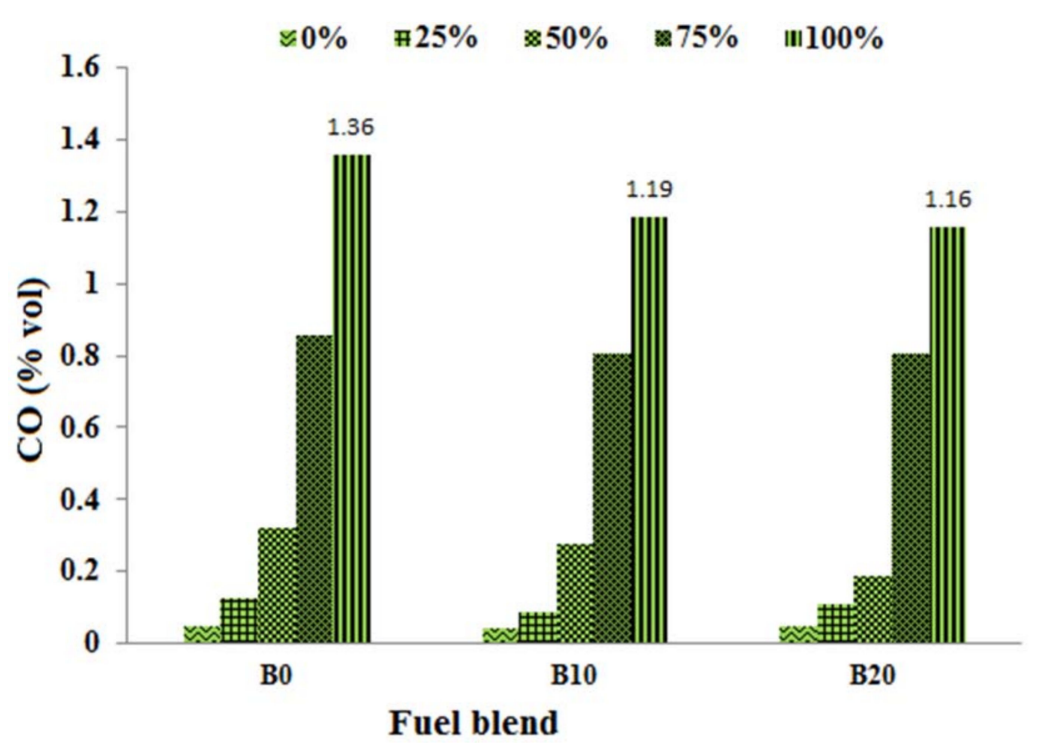

Figure 7. Results of carbon monoxide (CO) for different fuel blends at the constant speed of $2100 \mathrm{rpm}$.

\subsubsection{Carbon Dioxide $\left(\mathrm{CO}_{2}\right)$}

The effect of different blend fuels on carbon dioxide $\left(\mathrm{CO}_{2}\right)$ emission is shown in Figure 8. By increasing the biodiesel ratio, carbon dioxide $\left(\mathrm{CO}_{2}\right)$ increased. $\mathrm{CO}_{2}$ emission depends on the 
relative air-fuel ratio and $\mathrm{CO}$ emission concentration. As a result of the lean burning associated with increasing biodiesel, the $\mathrm{CO}_{2}$ emission increased because of the improved combustion [72-75].

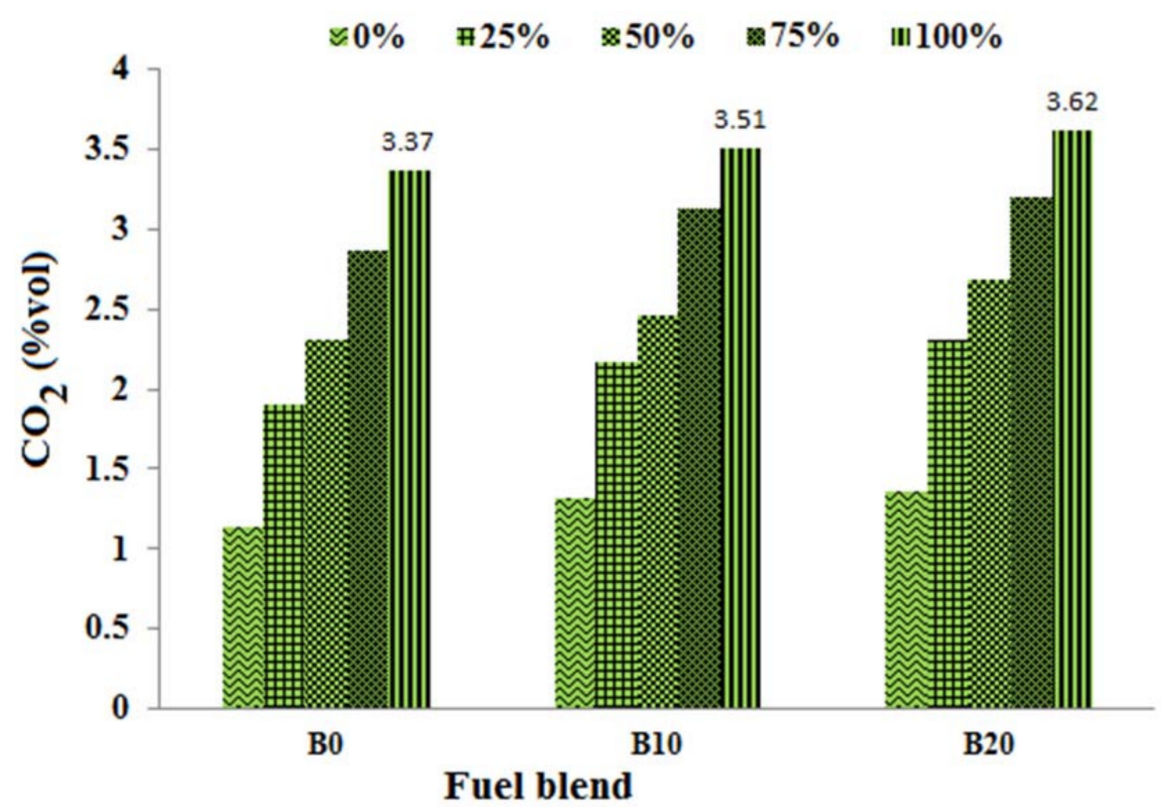

Figure 8. Results of carbon dioxide $\left(\mathrm{CO}_{2}\right)$ for different fuel blends at the constant speed of $2100 \mathrm{rpm}$.

\subsubsection{Unburned Hydrocarbons (UHC)}

Incomplete combustion is the main cause of the formation of unburned hydrocarbons (UHC). The unburned hydrocarbons (UHC) emissions for various fuel blends are shown in Figure 9. By increasing the Camelina "Soheil" ratio, UHC are significantly reduced. The use of oxygenated additives promotes complete combustion. Therefore, the hydrocarbon emissions are reduced [72]. The highest decrease for UHC is observed as 39\% for the B20 blend compared to the neat diesel fuel.

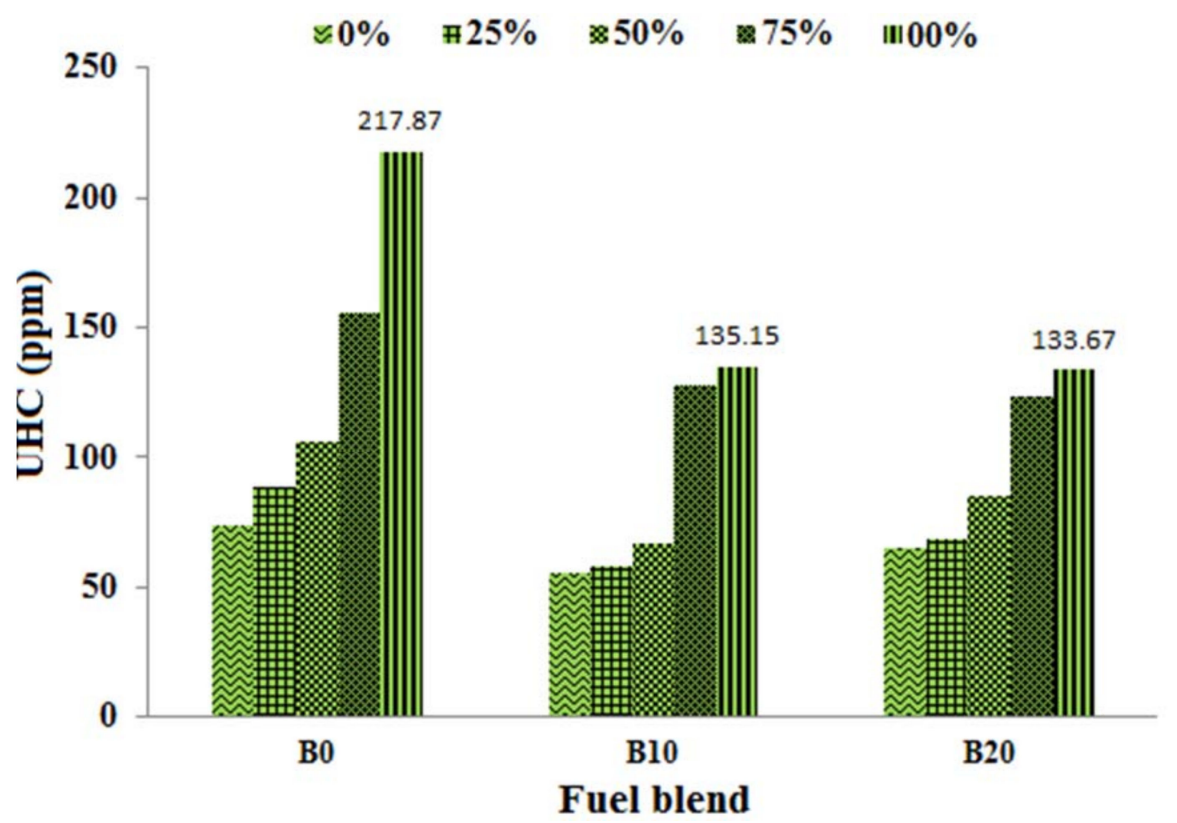

Figure 9. Results of unburned hydrocarbons (UHC) for different fuel blends at the constant speed of $2100 \mathrm{rpm}$. 


\subsubsection{Nitrogen Oxides (NOx)}

The variation of nitrogen oxides (NOx) emission with different fuel blends is shown in Figure 10. The amount of nitrogen oxides (NOx) emission of pure diesel fuel is somewhat lower than B10 and B20. The nitrogen oxides (NOx) for B10 and B20 are $13.11 \%$ and $22.54 \%$ higher than net-diesel (B0), respectively, due to the fact that the biodiesel has a higher oxygen content than diesel. Therefore, by using the biodiesel, nitrogen oxides (NOx) emission increased relative to diesel. The excess oxygen in the biodiesel increases the local temperature due to excess hydrocarbon oxidation, and when the oxygen levels increase, the maximum temperature during combustion increases. Then the formation of nitrogen oxides (NOx) increases [76].

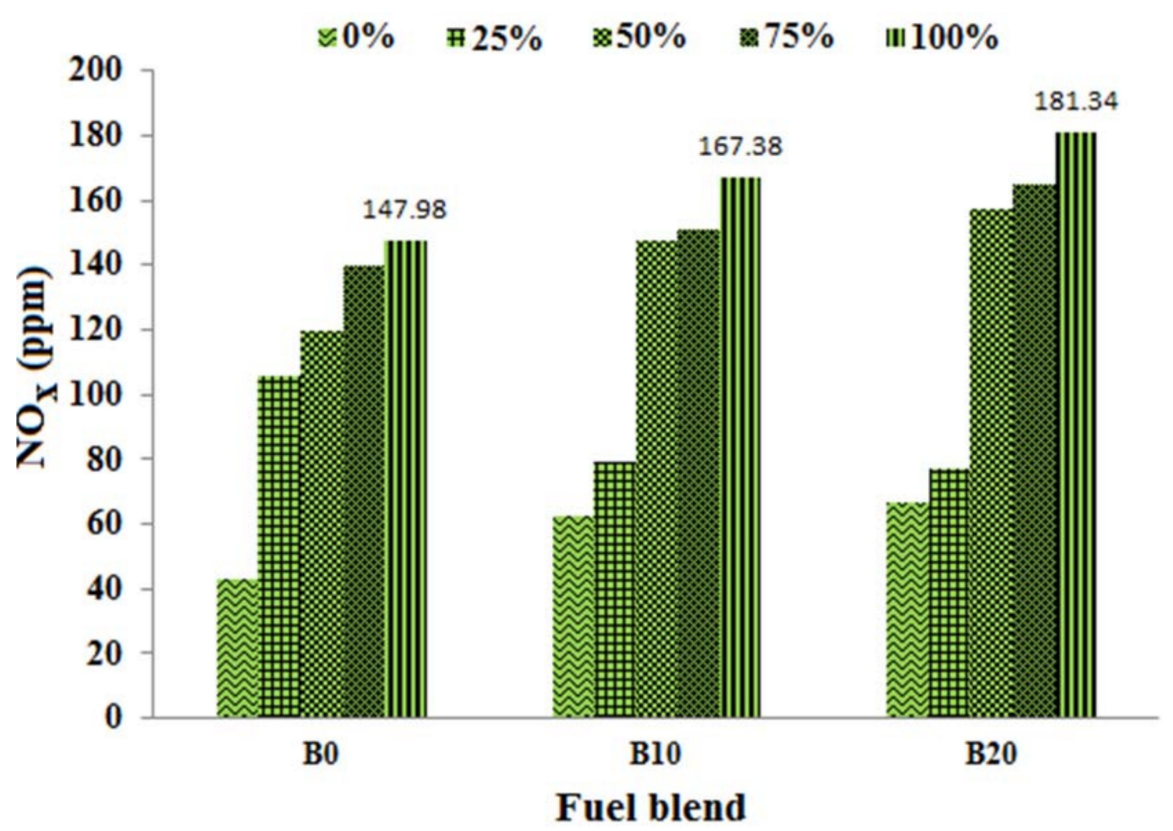

Figure 10. Results of nitrogen oxides (NOx) for different fuel blends at the constant speed of $2100 \mathrm{rpm}$.

\section{Comparison of Performance and Emission with Biodiesel Obtained from Camelina "Soheil" Seed Oil}

The present study found that Camelina "Soheil" has a significant impact on the performance parameters and emission characteristics of a diesel engine. Figure 11 illustrates the impact of the Camelina "Soheil" biodiesel on various engine parameters. According to Figure 11, biodiesel from Camelina "Soheil" has a very positive effect on all performance and emission parameters. 
Seed and oil of Camelina "Soheil"
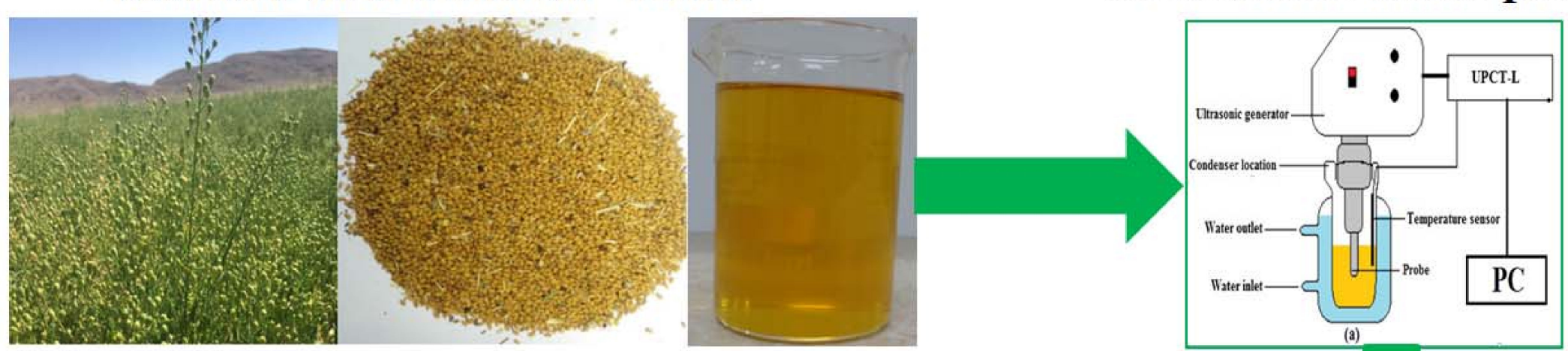

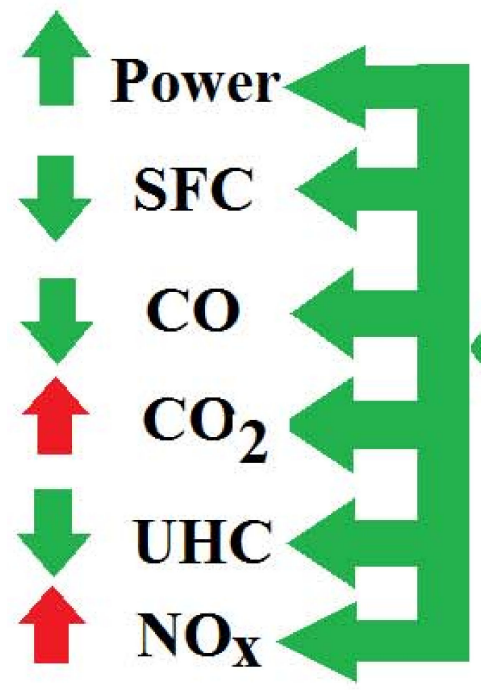

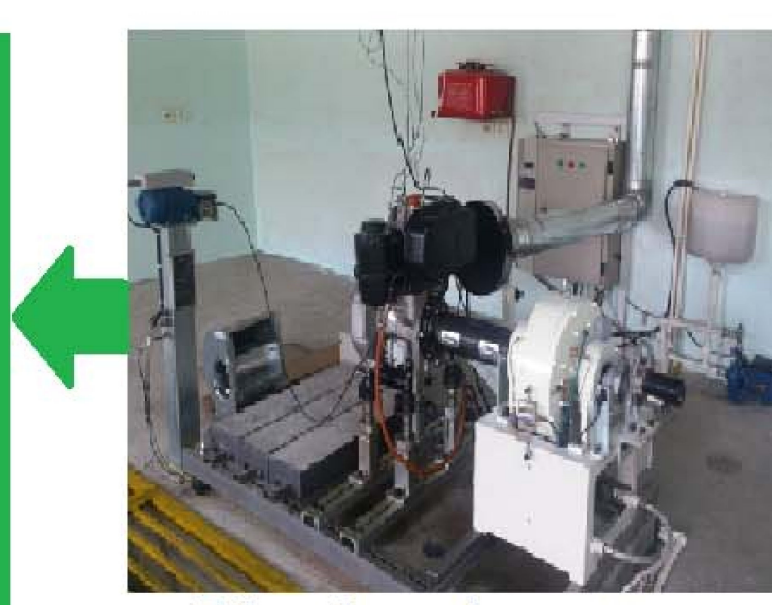

Diesel engine set-up

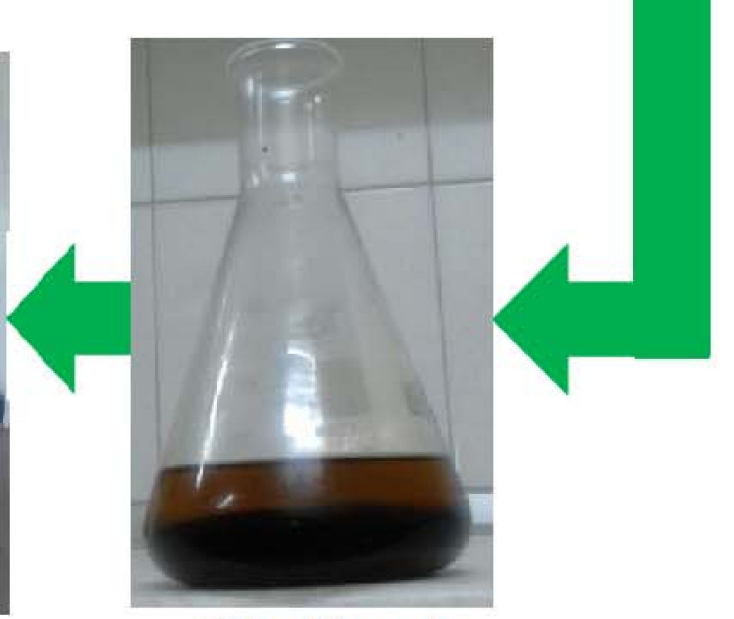

Biodiesel

Figure 11. Impact of the Camelina "Soheil" biodiesel on various engine parameters. 


\section{Conclusions}

In this study, biodiesel production from the new cultivar of Camelina "Soheil" was studied. After oil extraction, it was found that "Soheil" seed has $29 \%$ oil. The average yield of "Soheil" seed was 445-1112 kg per hectare. Therefore, the average yield of oil was 129-322 kg per hectare. As a result, the average biodiesel produced from "Soheil" is $129-322 \mathrm{~kg}$ per hectare. The process input variables, including molar ratio (methanol to oil), reaction time $(\mathrm{min})$ and catalyst concentration were optimized by response surface methodology (RSM) in order to reach the highest amount of methyl ester. After optimization of the input variables (molar ratio (methanol to oil) $=10.18: 1$, reaction time $=7.33 \mathrm{~min}$, and catalyst concentration $=1.15 \mathrm{wt} \%$ ), the rate of biodiesel production of $98.91 \%$ was experimentally achieved. An investigation of the physical and chemical characteristics of the biodiesel produced from "Soheil" oil determined that the physical and chemical characteristics of the biodiesel from "Soheil" oil meet the requirements of the ASTM D6751 standard. The engine test showed that by using the "Soheil" biodiesel, brake power was increased by $17 \%$. The improvement in engine power can be attributed to the increase of the indicated mean effective pressure for higher biodiesel concentration. Also, concentrations of the $\mathrm{CO}_{2}$, and $\mathrm{NO}_{x}$ emissions were increased by $7.5 \%$, and $15.22 \%$, respectively, because of the enhanced combustion, causing $\mathrm{NO}_{x}$ and $\mathrm{CO}_{2}$ to increase. However, the specific fuel consumption (SFC) was decreased by $15 \%$. Also, the concentrations of the $\mathrm{CO}$ and UHC emissions were decreased by $15 \%$ and $39 \%$, respectively, because of the enhanced combustion, causing CO and UHC to decrease.

Author Contributions: Conceptualization: S.S.H., G.N., B.G., and M.T.E. Formal analysis: S.S.H., G.N. and M.T.E. Funding acquisition: M.T.E. and G.N. Investigation: S.S.H., G.N., B.G., and M.T.E. Project administration: G.N. Supervision: G.N. Writing, original draft: S.S.H., Writing, review and editing: S.S.H., G.N., B.G., M.T.E. and T.Y.

Funding: This research received no external funding.

Conflicts of Interest: The authors declare no conflict of interest.

\section{List of Symbols and Acronyms}

$\begin{array}{ll}\text { B0 } & \text { Biodiesel } 0 \% \text { blend } \\ \text { B10 } & \text { Biodiesel 10\% blend } \\ \text { B20 } & \text { Biodiesel } 20 \% \text { blend } \\ \text { BP } & \text { Brake power } \\ \mathrm{CO} & \text { Carbon monoxide } \\ \mathrm{CO}_{2} & \text { Carbon dioxide } \\ \mathrm{CSO} & \text { Camelina "Soheil" seed oil } \\ \text { FAC } & \text { Fatty acid composition } \\ \mathrm{GC} & \text { Gas chromatography } \\ \mathrm{KOH} & \text { potassium hydroxide } \\ \mathrm{NaOCH} & \text { Sodium methoxide } \\ \mathrm{NOx} & \text { nitrogen oxide } \\ \mathrm{RSM} & \text { response surface methodology } \\ \mathrm{SFC} & \text { specific fuel consumption } \\ \mathrm{UHC} & \text { Unburned hydrocarbon }\end{array}$

\section{References}

1. Amaral, S.; Câmara, G.; Monteiro, A.M.V.; Quintanilha, J.A.; Elvidge, C.D. Estimating population and energy consumption in brazilian amazonia using DMSP night-time satellite data. Comput. Environ. Urban Syst. 2005, 29, 179-195. [CrossRef]

2. Holdren, J.P.; Ehrlich, P.R. Human population and the global environment: Population growth, rising per capita material consumption, and disruptive technologies have made civilization a global ecological force. Am. Sci. 1974, 62, 282-292. [PubMed] 
3. Nabi, M.N.; Akhter, M.S.; Shahadat, M.M.Z. Improvement of engine emissions with conventional diesel fuel and diesel-biodiesel blends. Bioresour. Technol. 2006, 97, 372-378. [CrossRef] [PubMed]

4. Abdel-Rahman, A. On the emissions from internal-combustion engines: A review. Int. J. Energy Res. 1998, 22, 483-513. [CrossRef]

5. Nelson, P.F.; Tibbett, A.R.; Day, S.J. Effects of vehicle type and fuel quality on real world toxic emissions from diesel vehicles. Atmos. Environ. 2008, 42, 5291-5303. [CrossRef]

6. Lapuerta, M.; Armas, O.; Rodriguez-Fernandez, J. Effect of biodiesel fuels on diesel engine emissions. Prog. Energy Combust. Sci. 2008, 34, 198-223. [CrossRef]

7. Amin, S. Review on biofuel oil and gas production processes from microalgae. Energy Convers. Manag. 2009, 50, 1834-1840. [CrossRef]

8. Peri, M.; Baldi, L. Vegetable oil market and biofuel policy: An asymmetric cointegration approach. Energy Econ. 2010, 32, 687-693. [CrossRef]

9. Boz, N.; Degirmenbasi, N.; Kalyon, D.M. Conversion of biomass to fuel: Transesterification of vegetable oil to biodiesel using KF loaded nano- $\gamma-\mathrm{Al}_{2} \mathrm{O}_{3}$ as catalyst. Appl. Catal. B Environ. 2009, 89, 590-596. [CrossRef]

10. Lee, H.V.; Yunus, R.; Juan, J.C.; Taufiq-Yap, Y.H. Process optimization design for jatropha-based biodiesel production using response surface methodology. Fuel Process. Technol. 2011, 92, 2420-2428. [CrossRef]

11. Basha, S.A.; Gopal, K.R.; Jebaraj, S. A review on biodiesel production, combustion, emissions and performance. Renew. Sustain. Energy Rev. 2009, 13, 1628-1634. [CrossRef]

12. Cárdenas, M.D.; Armas, O.; Mata, C.; Soto, F. Performance and pollutant emissions from transient operation of a common rail diesel engine fueled with different biodiesel fuels. Fuel 2016, 185, 743-762. [CrossRef]

13. Lapuerta, M.; Villajos, M.; Agudelo, J.R.; Boehman, A.L. Key properties and blending strategies of hydrotreated vegetable oil as biofuel for diesel engines. Fuel Process. Technol. 2011, 92, 2406-2411. [CrossRef]

14. Freedman, B.; Pryde, E.; Mounts, T. Variables affecting the yields of fatty esters from transesterified vegetable oils. J. Am. Oil Chem. Soc. 1984, 61, 1638-1643. [CrossRef]

15. Demirbas, A. Comparison of transesterification methods for production of biodiesel from vegetable oils and fats. Energy Convers. Manag. 2008, 49, 125-130. [CrossRef]

16. Atabani, A.; Silitonga, A.; Ong, H.; Mahlia, T.; Masjuki, H.; Badruddin, I.A.; Fayaz, H. Non-edible vegetable oils: A critical evaluation of oil extraction, fatty acid compositions, biodiesel production, characteristics, engine performance and emissions production. Renew. Sustain. Energy Rev. 2013, 18, 211-245. [CrossRef]

17. Rawat, I.; Kumar, R.R.; Mutanda, T.; Bux, F. Biodiesel from microalgae: A critical evaluation from laboratory to large scale production. Appl. Energy 2013, 103, 444-467. [CrossRef]

18. Mucak, A.; Karabektas, M.; Hasimoglu, C.; Ergen, G. Performance and emission characteristics of a diesel engine fuelled with emulsified biodiesel-diesel fuel blends. Int. J. Autom. Eng. Technol. 2016, 5, 176-185.

19. Faried, M.; Samer, M.; Abdelsalam, E.; Yousef, R.S.; Attia, Y.A.; Ali, A.S. Biodiesel production from microalgae: Processes, technologies and recent advancements. Renew. Sustain. Energy Rev. 2017, 79, 893-913. [CrossRef]

20. Shah, S.H.; Raja, I.A.; Rizwan, M.; Rashid, N.; Mahmood, Q.; Shah, F.A.; Pervez, A. Potential of microalgal biodiesel production and its sustainability perspectives in pakistan. Renew. Sustain. Energy Rev. 2018, 81, 76-92. [CrossRef]

21. Bueno, A.V.; Pereira, M.P.B.; de Oliveira Pontes, J.V.; de Luna, F.M.T.; Cavalcante, C.L. Performance and emissions characteristics of castor oil biodiesel fuel blends. Appl. Therm. Eng. 2017, 125, 559-566. [CrossRef]

22. Roy, M.M.; Wang, W.; Alawi, M. Performance and emissions of a diesel engine fueled by biodiesel-diesel, biodiesel-diesel-additive and kerosene-biodiesel blends. Energy Convers. Manag. 2014, 84, 164-173. [CrossRef]

23. Dharma, S.; Masjuki, H.H.; Ong, H.C.; Sebayang, A.H.; Silitonga, A.S.; Kusumo, F.; Mahlia, T.M.I. Optimization of biodiesel production process for mixed Jatropha curcas-Ceiba pentandra biodiesel using response surface methodology. Energy Convers. Manag. 2016, 115, 178-190. [CrossRef]

24. Hoseini, S.S.; Najafi, G.; Ghobadian, B.; Rahimi, A.; Yusaf, T.; Mamat, R.; Sidik, N.A.C.; Azmi, W.H. Effects of biodiesel fuel obtained from salvia macrosiphon oil (ultrasonic-assisted) on performance and emissions of diesel engine. Energy 2017, 131, 289-296. [CrossRef]

25. Castro Gonzáles, N.F. International experiences with the cultivation of Jatropha curcas for biodiesel production. Energy 2016, 112, 1245-1258. [CrossRef] 
26. Yang, P.-M.; Lin, K.C.; Lin, Y.-C.; Jhang, S.-R.; Chen, S.-C. Emission evaluation of a diesel engine generator operating with a proportion of isobutanol as a fuel additive in biodiesel blends. Appl. Therm. Eng. 2016, 100, 628-635. [CrossRef]

27. Srinivasa Rao, M.; Anand, R.B. Performance and emission characteristics improvement studies on a biodiesel fuelled DICI engine using water and $\mathrm{ALO}(\mathrm{OH})$ nanoparticles. Appl. Therm. Eng. 2016, 98, 636-645. [CrossRef]

28. Maghami, M.; Sadrameli, S.M.; Ghobadian, B. Production of biodiesel from fishmeal plant waste oil using ultrasonic and conventional methods. Appl. Therm. Eng. 2015, 75, 575-579. [CrossRef]

29. Tutak, W.; Jamrozik, A.; Pyrc, M.; Sobiepański, M. A comparative study of co-combustion process of diesel-ethanol and biodiesel-ethanol blends in the direct injection diesel engine. Appl. Therm. Eng. 2017, 117, 155-163. [CrossRef]

30. Khoobbakht, G.; Najafi, G.; Karimi, M.; Akram, A. Optimization of operating factors and blended levels of diesel, biodiesel and ethanol fuels to minimize exhaust emissions of diesel engine using response surface methodology. Appl. Therm. Eng. 2016, 99, 1006-1017. [CrossRef]

31. Nabi, M.N.; Rahman, M.M.; Akhter, M.S. Biodiesel from cotton seed oil and its effect on engine performance and exhaust emissions. Appl. Therm. Eng. 2009, 29, 2265-2270. [CrossRef]

32. Hoseini, S.S.; Najafi, G.; Ghobadian, B.; Mamat, R.; Ebadi, M.T.; Yusaf, T. Ailanthus altissima (tree of heaven) seed oil: Characterisation and optimisation of ultrasonication-assisted biodiesel production. Fuel 2018, 220, 621-630. [CrossRef]

33. Hoseini, S.S.; Najafi, G.; Ghobadian, B.; Mamat, R.; Sidik, N.A.C.; Azmi, W.H. The effect of combustion management on diesel engine emissions fueled with biodiesel-diesel blends. Renew. Sustain. Energy Rev. 2017, 73, 307-331. [CrossRef]

34. Patil, P.D.; Gude, V.G.; Deng, S. Biodiesel production from Jatropha curcas, waste cooking, and Camelina sativa oils. Ind. Eng. Chem. Res. 2009, 48, 10850-10856. [CrossRef]

35. Gunawan, S.; Maulana, S.; Anwar, K.; Widjaja, T. Rice bran, a potential source of biodiesel production in Indonesia. Ind. Crop. Prod. 2011, 33, 624-628. [CrossRef]

36. Zanuttini, M.S.; Pisarello, M.L.; Querini, C.A. Butia yatay coconut oil: Process development for biodiesel production and kinetics of esterification with ethanol. Energy Convers. Manag. 2014, 85, 407-416. [CrossRef]

37. Hajinezhad, A.; Abedi, S.; Ghobadian, B.; Noorollahi, Y. Biodiesel production from norouzak (Salvia lerifolia) seeds as an indigenous source of bio fuel in iran using ultrasound. Energy Convers. Manag. 2015, 99, 132-140. [CrossRef]

38. Silveira Junior, E.G.; Simionatto, E.; Perez, V.H.; Justo, O.R.; Zárate, N.A.H.; Vieira, M.d.C. Potential of virginia-type peanut (Arachis hypogaea L.) as feedstock for biodiesel production. Ind. Crop. Prod. 2016, 89, 448-454. [CrossRef]

39. Kakati, J.; Gogoi, T.K. Biodiesel production from kutkura (Meyna spinosa roxb. Ex.) fruit seed oil: Its characterization and engine performance evaluation with $10 \%$ and $20 \%$ blends. Energy Convers. Manag. 2016, 121, 152-161. [CrossRef]

40. Ijaz, M.; Bahtti, K.H.; Anwar, Z.; Dogar, U.F.; Irshad, M. Production, optimization and quality assessment of biodiesel from Ricinus communis L. Oil. J. Radiat. Res. Appl. Sci. 2016, 9, 180-184. [CrossRef]

41. Soukht Saraee, H.; Jafarmadar, S.; Sayadi, M.; Parikhani, A.; Kheyrollahi, J.; Pourvosoughi, N. Green fuel production from Pistacia khinjuk and its engine test analysis as a promising alternative. J. Clean. Prod. 2017, 156, 106-113. [CrossRef]

42. Fröhlich, A.; Rice, B. Evaluation of Camelina sativa oil as a feedstock for biodiesel production. Ind. Crop. Prod. 2005, 21, 25-31. [CrossRef]

43. Bernardo, A.; Howard-Hildige, R.; O'Connell, A.; Nichol, R.; Ryan, J.; Rice, B.; Roche, E.; Leahy, J.J. Camelina oil as a fuel for diesel transport engines. Ind. Crops Prod. 2003, 17, 191-197. [CrossRef]

44. Kruczyński, S.W. Performance and emission of ci engine fuelled with Camelina sativa oil. Energy Convers. Manag. 2013, 65, 1-6. [CrossRef]

45. Moser, B.R.; Vaughn, S.F. Evaluation of alkyl esters from Camelina sativa oil as biodiesel and as blend components in ultra low-sulfur diesel fuel. Bioresour. Technol. 2010, 101, 646-653. [CrossRef] [PubMed]

46. Yang, J.; Caldwell, C.; Corscadden, K.; He, Q.S.; Li, J. An evaluation of biodiesel production from Camelina sativa grown in Nova Scotia. Ind. Crop. Prod. 2016, 81, 162-168. [CrossRef] 
47. Emiroğlu, A.O.; Şen, M. Combustion, performance and exhaust emission characterizations of a diesel engine operating with a ternary blend (alcohol-biodiesel-diesel fuel). Appl. Therm. Eng. 2018, 133, 371-380. [CrossRef]

48. Geng, P.; Mao, H.; Zhang, Y.; Wei, L.; You, K.; Ju, J.; Chen, T. Combustion characteristics and nox emissions of a waste cooking oil biodiesel blend in a marine auxiliary diesel engine. Appl. Therm. Eng. 2017, 115, 947-954. [CrossRef]

49. Ibrahim, A. Performance and combustion characteristics of a diesel engine fuelled by butanol-biodiesel-diesel blends. Appl. Therm. Eng. 2016, 103, 651-659. [CrossRef]

50. Raziei, Z.; Kahrizi, D.; Rostami-Ahmadvandi, H. Effects of climate on fatty acid profile in Camelina sativa. Cell. Mol. Biol. 2018, 64, 91-96. [CrossRef] [PubMed]

51. Maccarone, E.; Fallico, B.; Fanella, F.; Mauromicale, G.; Raccuia, S.; Foti, S. Possible alternative utilization of Cynara spp.: Ii. Chemical characterization of their grain oil. Ind. Crop. Prod. 1999, 10, 229-237. [CrossRef]

52. Metcalfe, L.; Schmitz, A.A.; Pelka, J. Rapid preparation of fatty acid esters from lipids for gas chromatographic analysis. Anal. Chem. 1966, 38, 514-515. [CrossRef]

53. Van Gerpen, J. Biodiesel processing and production. Fuel Process. Technol. 2005, 86, 1097-1107. [CrossRef]

54. Mani, M.; Nagarajan, G. Influence of injection timing on performance, emission and combustion characteristics of a di diesel engine running on waste plastic oil. Energy 2009, 34, 1617-1623. [CrossRef]

55. Kannan, G.R.; Karvembu, R.; Anand, R. Effect of metal based additive on performance emission and combustion characteristics of diesel engine fuelled with biodiesel. Appl. Energy 2011, 88, 3694-3703. [CrossRef]

56. Nehdi, I.A.; Sbihi, H.M.; Al-Resayes, S.I. Rhazya stricta decne seed oil as an alternative, non-conventional feedstock for biodiesel production. Energy Convers. Manag. 2014, 81, 400-406. [CrossRef]

57. Koh, M.Y.; Ghazi, T.I.M. A review of biodiesel production from Jatropha curcas L. Oil. Renew. Sustain. Energy Rev. 2011, 15, 2240-2251. [CrossRef]

58. Silitonga, A.; Masjuki, H.; Mahlia, T.; Ong, H.C.; Kusumo, F.; Aditiya, H.; Ghazali, N. Schleichera oleosa L. oil as feedstock for biodiesel production. Fuel 2015, 156, 63-70. [CrossRef]

59. Gao, L.; Xu, B.; Xiao, G.; Lv, J. Transesterification of palm oil with methanol to biodiesel over a KF/hydrotalcite solid catalyst. Energy Fuels 2008, 22, 3531-3535. [CrossRef]

60. Sivakumar, P.; Sindhanaiselvan, S.; Gandhi, N.N.; Devi, S.S.; Renganathan, S. Optimization and kinetic studies on biodiesel production from underutilized Ceiba pentandra oil. Fuel 2013, 103, 693-698. [CrossRef]

61. Apostolakou, A.; Kookos, I.; Marazioti, C.; Angelopoulos, K. Techno-economic analysis of a biodiesel production process from vegetable oils. Fuel Process. Technol. 2009, 90, 1023-1031. [CrossRef]

62. Dias, J.M.; Alvim-Ferraz, M.C.; Almeida, M.F. Comparison of the performance of different homogeneous alkali catalysts during transesterification of waste and virgin oils and evaluation of biodiesel quality. Fuel 2008, 87, 3572-3578. [CrossRef]

63. Armas, O.; Martínez-Martínez, S.; Mata, C. Effect of an ethanol-biodiesel-diesel blend on a common rail injection system. Fuel Process. Technol. 2011, 92, 2145-2153. [CrossRef]

64. Pereira, R.G.; Oliveira, C.D.; Oliveira, J.L.; Oliveira, P.C.P.; Fellows, C.E.; Piamba, O.E. Exhaust emissions and electric energy generation in a stationary engine using blends of diesel and soybean biodiesel. Renew. Energy 2007, 32, 2453-2460. [CrossRef]

65. Karmakar, A.; Karmakar, S.; Mukherjee, S. Properties of various plants and animals feedstocks for biodiesel production. Bioresour. Technol. 2010, 101, 7201-7210. [CrossRef] [PubMed]

66. Ejim, C.; Fleck, B.; Amirfazli, A. Analytical study for atomization of biodiesels and their blends in a typical injector: Surface tension and viscosity effects. Fuel 2007, 86, 1534-1544. [CrossRef]

67. Nehdi, I.A.; Sbihi, H.; Tan, C.P.; Al-Resayes, S.I. Garden cress (Lepidium sativum Linn.) seed oil as a potential feedstock for biodiesel production. Bioresour. Technol. 2012, 126, 193-197. [CrossRef] [PubMed]

68. Lü, X.-C.; Yang, J.-G.; Zhang, W.-G.; Huang, Z. Effect of cetane number improver on heat release rate and emissions of high speed diesel engine fueled with ethanol-diesel blend fuel. Fuel 2004, 83, 2013-2020.

69. İçıngür, Y.; Altiparmak, D. Effect of fuel cetane number and injection pressure on a di diesel engine performance and emissions. Energy Convers. Manag. 2003, 44, 389-397. [CrossRef]

70. Bayraktar, H. Experimental and theoretical investigation of using gasoline-ethanol blends in spark-ignition engines. Renew. Energy 2005, 30, 1733-1747. [CrossRef] 
71. Celik, M.B. Experimental determination of suitable ethanol-gasoline blend rate at high compression ratio for gasoline engine. Appl. Therm. Eng. 2008, 28, 396-404. [CrossRef]

72. Selvan, V.A.M.; Anand, R.; Udayakumar, M. Effects of cerium oxide nanoparticle addition in diesel and diesel-biodiesel-ethanol blends on the performance and emission characteristics of a ci engine. J. Eng. Appl. Sci. 2009, 4, 1819-6608.

73. Al-Hasan, M. Effect of ethanol-unleaded gasoline blends on engine performance and exhaust emission. Energy Convers. Manag. 2003, 44, 1547-1561. [CrossRef]

74. Hsieh, W.-D.; Chen, R.-H.; Wu, T.-L.; Lin, T.-H. Engine performance and pollutant emission of an SI engine using ethanol-gasoline blended fuels. Atmos. Environ. 2002, 36, 403-410. [CrossRef]

75. Wu, C.-W.; Chen, R.-H.; Pu, J.-Y.; Lin, T.-H. The influence of air-fuel ratio on engine performance and pollutant emission of an SI engine using ethanol-gasoline-blended fuels. Atmos. Environ. 2004, 38, 7093-7100. [CrossRef]

76. Ozsezen, A.N.; Canakci, M. Determination of performance and combustion characteristics of a diesel engine fueled with canola and waste palm oil methyl esters. Energy Convers. Manag. 2011, 52, 108-116. [CrossRef]

(C) 2018 by the authors. Licensee MDPI, Basel, Switzerland. This article is an open access article distributed under the terms and conditions of the Creative Commons Attribution (CC BY) license (http://creativecommons.org/licenses/by/4.0/). 